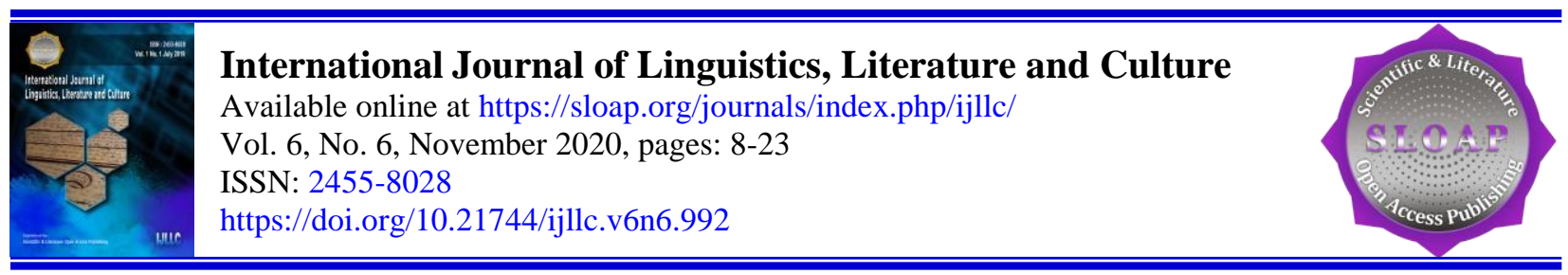

\title{
Conflict within Tri Hita Karana's Fields: A Conceptual Review
}

I Nyoman Sudama ${ }^{\text {a }}$

Article history:

Submitted: 18 July 2020

Revised: 09 August 2020

Accepted: 27 September 2020

\section{Keywords:}

Balinese;

capital;

conflict;

fields;

Tri Hita Karana;

\begin{abstract}
The study on Tri Hita Karana mostly focuses on the application of the concept in particular area. Its lack of conjectural discussion opens opportunities for further research. Specifically, conflict is infrequently embraced, despite the fact that dispute is inevitably part of another Balinese balance concept, namely, rwa bhineda. This paper aims to draft a discourse of THK within the standpoint of cultural sociology by tailoring several concepts to identify the raise and possibility of conflict in Balinese social systems. Thence, the paper first reviews THK literatures to examine research conceptions on THK within Balinese customs. Second, the paper proposes extended THK framework to illustrate how conflict can emerge in Balinese practices and explain further understanding of interrelation of THK's worlds. This paper highlights how the THK can be seen from cultural sociology perspectives to frame the dynamic of Balinese traditions within the contestation of spiritual, nature, and human fields. This study shows that capital play important roles on the Balinese life balance. Capital determines the positions, statuses, competitions, and hence symbolic values of agents in the fields. The paper advocates future theory developments to construct on different framework of THK to better describe the Balinese transitions toward modern cultures.
\end{abstract}

International journal of linguistics, literature and culture () 2020. This is an open access article under the CC BY-NC-ND license (https://creativecommons.org/licenses/by-nc-nd/4.0/).

Corresponding author:

I Nyoman Sudama,

Indonesian Institute of Police Science (STIK-PTIK) Jakarta, Indonesia.

Email address: nsdama@gmail.com

${ }^{a}$ Indonesian Institute of Police Science (STIK-PTIK) Jakarta, Indonesia 


\section{Introduction}

Tri Hita Karana (THK) has been acknowledged by a lot of kinds of literature as a concept of well-being and happiness (Aditya \& Kusuma, 2019; Atmadja et al., 2019; Norken et al., 2017; Suamba \& Sutama, 2017; Kusuma et al., 2019). However, recent works, primarily in the fields of Balinese tourism development, have focused mostly on analyzing THK in the tourism development framework to see the well-being impact of tourism on the Balinese community (Pickel-Chevalier \& Budarma, 2016; Suamba \& Sutama, 2017; Astuti et al., 2018; Adityanandana \& Gerber, 2019; Kusuma et al., 2019). Some scholars are interested in discussing the concept with sustainability and environment including the Balinese traditional irrigation system (subak) in the agriculture sector (Suweta, 2015; Sutawan, 2004; Norken et al., 2017). Although the THK is famously scrutinized as a harmonious life notion within Balinese communities, some analyses refer to THK as disagreement aspects of agents in the Balinese social systems (Suarniati et al., 2019; Atmadja et al., 2019).

Studies on Balinese culture have different conceptual approaches to justify THK. Policymakers analyze THK about development strategies and academicians focus on educational learning theories. Experts in human society investigate THK with social notions while others take behavior concepts as a center of attention. The studies have one thing in common that is they view THK as a balance and wellbeing disposition. Although, some of them relate THK to conflict as disturbances of social equilibrium how it happens is unclear.

Conflict resolution strategies as policing activities are getting tougher and strenuous. With the increase of conflicts at various forms and sources in modern life, policing activities have to deal with enlarge responsibilities to find conflict solutions at the community level. The sources of conflict also rise and vary from simple daily life problems to complex global terrorist chains. Therefore, there is an increasing need for law-enforcing agencies to understand, know, and analyze the root of the conflict and hence its framework to gain new perspectives of conflict resolution.

The literature on conflict resolution provides methods to improve our social resilience but some of them fail to offer appropriate approaches when they disregard interests and identity (Mutisya, 2011). Focus on interests and identity is extremely important in finding the root of conflicts of human relations (Ringmar, 1996; Rothman \& Olson, 2001; Abouelsaood et al., 1987). Based on the identity and interests point of view, conflict occurs when people are misguided by their social, political, and economic attentions and misconceived by their norms, beliefs, practices, and traditions ${ }^{\mathrm{b}}$.

This paper aims to examine the roots of conflict between interest and identity by adopting THK structures. In the Balinese context, the sources of conflict are mainly rooted in the imbalance of spiritual, human, and natural worlds in which interests and identity in the forms of capital and traditions are the primary dynamic forces (Peters \& Wardana, 2013; Suartika, 2005). It is crucial to understand how the feeling of wanting a particular capital in the framework of Balinese identity to enhance the quality of realistic analysis for policing activities or law-enforcement agencies (Wang, 1990; Solnik, 1974). The THK concept in conflict framework is thus an important approach in conflict resolution and hence conflict transformation.

This paper proposes an extended THK arrangement to understand its connection with conflict based on theoretical synthesis that tailoring any conceptual substructures in the cultural sociological contexts. The extension shows that the THK can be seen as interests and identity conflict frameworks for sustainable conflict resolution. The presented scheme is the contestation of capital between spiritual, natural, and human fields. The mixed review methodologies utilize in this study also depict that there are capital transformations in the THK's fields that trade-off the harmonies and frictions that affect the dynamic of Balinese social systems. Therefore, the newly developed THK notions fill the gap in literature to show that the well-being, balance, and happiness structures could also be seen as the framework of conflict by putting other concepts as a complement for deeper understanding.

This paper will focus on the THK defined in Siadis (2014) and Adityanandana (2017) and adopts the definition of the capital of Pierre Bourdieu (1986) ${ }^{\mathrm{c}}$. It attempts to connect Bourdieu's sociology approaches and THK to bring the interrelation within a comprehensive framework of conflict formation. Consequently, constructing the framework of conflict analysis requires to synchronize concepts of Galtung's ABC conflict triangle (Galtung, 1996), for composite and well established Bourdieu-THK framework analysis. For that reason, this paper pursues to improve the existing THK framework through the straightforward insertion of field, capital, conflict, and creativity concepts to better perceive the intended apparatus through which balance and conflict are fabricated and eventually discovered.

\footnotetext{
${ }^{b}$ Mutisya explains that interest involves occupational, social, political, and economic aspirations while identity is related to norms, beliefs, practices, and traditions.

${ }^{c}$ Bourdieu (1986) defines capital as economic capital, cultural capital, social capital and symbolic capital. Sudama, I. N. (2020). Conflict within tri hita karana's fields: A conceptual review. International Journal of Linguistics, Literature and Culture, 6(6), 8-23. https://doi.org/10.21744/ijllc.v6n6.992
} 
This paper is not designated to oppose with the study of THK as a balance harmonious view or sustainability notion. Rather, it proposes an additional framework for the understanding of the cause of conflict in Balinese communities ${ }^{\mathrm{d}}$. This paper employs mixed semi-systematic and integrative review, conceptual approach, and practitioner-based inquiry methodologies to augment the THK notion specifically associated with the field, capital, conflict, and creativity concepts (Ruble \& Thomas, 1976). Below, the paper first explains the research method, then gives a brief review of THK, Bourdieu's theory, conflict, and creativity, then forms the extended THK framework, and finally explains and discusses the proposed framework about Balinese socio-economic interests and their dynamic identity.

\section{Materials and Methods}

The search for the literature of THK utilizes the Google search, online publications, the Google scholar, and journal websites with keywords of Bali culture and Tri Hita Karana. There is no time limitation on the publications and no restriction on the research methodologies. This consideration is purposely designed since the review in the THK concept is hardly conducted. Only 37 of the THK studies from the search are selected as mimicking a purposive sampling or a subjective non-probability selection.

Among the systematic, semi-systematic, and integrative review, this research outline the conflict theory in the framework of capital and field as a background of spiritual, natural, and human relations in Bali. This study critically reviews by innovating a basic concept of previous theories on culture and conflict to propose a framework in the form of a flowchart as a theoretical foundation for further research. Therefore the literature review as a method of this study stands between semi-systematic and integrative review (Snyder, 2019). Three main questions to guide the findings of the reviews are as follows:

1) What are the key themes or subjects of discussions of the THK literature?

2) How the THK concept is explored by the method used in the analysis?

3) To what extent is the THK concept match with the purpose of the study and its findings?

The methodology of this research differs from the factual analysis in some elements explained in Jaakkola (2020) who cited the table of Lukka \& Vinnari (2014): (1) this research employs theories and concepts to initiate comprehensive intuitions; (2) this research uses theories and concepts as data for discussion and analysis; (3) the unit of analysis is the point of views and the intensity of the analysis; and (4) this paper presents concepts integration and discussion as a method to data analysis.

This method will also utilize a practitioner-based inquiry in which researchers as the ones that experience their research field. Therefore, they enquire about their practices and make a report or research paper based on the analysis of participation in the field of studies. This paper is also based on some experiences as Balinese and involvements in conflict resolution. Therefore, this paper is a kind of a self-reporting experience in a conceptual analysis that is part of a practitioner-based inquiry research methodology. Part of the analysis of this paper is outlined to illustrate the connections of knowledge and the author's life experiences as an essential step in a practitioner-based inquiry (Demetrion, 2000; Gordon, 2016).

\section{Field and Capital}

Pierre Bourdieu (1930-2002) is well known for his theory of sociology as well as a sociological study of culture (Fowler, 1999; Bennet, 2005; Lizardo, 2011; Asimaki \& Koustourakis, 2014). The legacy and impact of Bourdieu's concept of field, habitus, and capital to the numerous analyses of sociology, culture, economics, anthropology, linguistic, and philosophy is incontrovertible. From these three prominent notions, the theory of practice is formulated as how agent habitus and their associated capital within particular fields are connected (Asimaki \& Koustourakis, 2014). Theories of field and capital have helped to simplify the social system as a unit of analysis to gain a deeper understanding of social structures. It is the fields that pave a way for giving a boundary of the analysis in a certain area of studies that needs logical reasoning of practices ${ }^{\mathrm{e}}$.

\footnotetext{
${ }^{d}$ Parker (2011: 19) notices that the Bali's terrorist bombing in 2002 and 2004 changed the view of Balinese toward its harmonious life concept in which a cultural movement was needed for new peaceful spirit of Bali Island. However, the cultural movement is lack of definition with various unclear agendas (Allen \& Palermo, 2005) that end up with several conflicts including mass organisation disputes (McDonald and Wilson, 2017; Izawa, 2009)

${ }^{e}$ For the purpose of this study, only fields and capital is relevance and mostly employ in the conceptual framework
} 
The field is defined as space where objective relations among agent intentions occur in which the intentions are the objective characterization of the agents structured by capital distributions (Bennett \& Silva, 2006; Chan, 2004; Grusendorf, 2016). Bourdieu uses the term game to envisage a mental idea of the field that has its own specific rules to govern the agents as field players (Shammas \& Sandberg, 2016). Therefore, there are individuals, groups, organizations, institutions, specific interest communities, relations, communications, exercises, and practicalities in the field. These Bourdieu perspectives make the field different from social networks in the form of capital since Bourdieu more concerned with the structure of the interactions (Bottero \& Crossley, 2011). Consequently, the core analyses of Bourdieusian mostly focus on the field as a social structure with capital as a power of struggle (Croce, 2019) .

Bourdieu (1986) argues that the capital must be part of the social world of which dictates practices for larger possibilities. Bourdieu (1986) states that

"It is in fact impossible to account for the structure and functioning of the social world unless one reintroduces capital in all its forms and not solely in the one form recognized by economic theory".

Bourdieu introduces four kinds of capital such as economic capital, social capital, cultural capital, and symbolic capital. Economic capital is the capital that mostly discusses economic theories as a value of the exchange of ownership. Social capital is defined as networks of connections that give a certain advantage to people who have it. Cultural capital can be specified as educational attainment or a degree from a certain level of an educational institution. Symbolic capital is a product of an agent's creativity in the fields (Velikovsky, 2018).

Capital distributions in particular fields differ in size, amount, degree, or nature and there is association or interlink between fields which in turn change capital from one condition, form, or state to another (Wilterdink, 2017). Capital can be converted from one form to another trough capital transformations and trade mechanisms (Bourdieu, 1986). Different distributions of capital among fields are the source of social inequalities that vary among societies and dynamically fluctuates in different periods (Wilterdink, 2017).

\section{Tri Hita Karana (THK)}

THK is a universal concept that grows without formally mentioned in Balinese holy manuscripts for religious references like Gita, Weda, or Sarasamuscaya. It has been widely introduced as Balinese cultural capital implemented in Balinese tourism development (Sumadi, 2016; Purnaya, 2016; Astuti et al., 2018, Ginaya et al., 2019). Its existence as an omnipresent concept was developed along with other Balinese philosophies as a life practice. Like most of the concepts built-in Bali after the influence of Siwa-Budha, THK found its meaning about Balinese abilities to combine religion with local wisdom ${ }^{\mathrm{g}}$. Therefore the concept is formed as a result of an understanding of real-life in the framework of values or norms adopted from outsiders.

As a philosophy of life, THK has been accepted as the most important principle of balance and harmony between physical and spiritual worlds (Wesnawa \& Sudirta, 2017; Purnaya, 2016, Triyuni et al., 2019). The balance relations among parhyangan (spiritual), palemahan (environment or nature), and pawongan (human) are the goal of human life in Balinese perspectives. A disruption among these relations will end up in vertical or horizontal conflict. Therefore, Balinese culture has been back up by the effort to maintain these three triangles in harmony to create happiness among human beings.

Ardika mentioned that THK is a concept that implicitly imposes human consciousness. Therefore, human action must be in the limit of the boundary of the three worlds of THK ${ }^{\mathrm{h}}$. This view means that actions or attitudes and

\footnotetext{
${ }^{f}$ In this paper the habitus seem likely less dominant to give more conceptual framework and also to simplify the overlapping and complexities of the frameworks, it is imperative to focus on the Bourdieu field and its constituted capital as the core conceptual framing. As Croce (2019) pointed out that

"This means that, strictly speaking, the habitus cannot be said to mechanically determine people's actions. Instead, it affects their schemes of perception through which they understand what is appropriate and what is not in a given context. Thus, a theory that seizes on the notion of habitus intends to capitalize on the basic conclusion that certain schemes of perception make certain political alternatives invisible, unspeakable and thus impossible to verbalize or even imagine." the habitus concept can be implied in the analysis of field and capital framework like this paper.

${ }^{g}$ There are some concepts has been developed as acculturation of religion such as tat twam asi, thri kaya parisuda, rwa binheda, just to name a view.

${ }^{h}$ I Gede Ardika is a minister of culture and tourism of Republic of Indonesia in the period of 2000-2004 who giving a preface of Peters and Wardana (2013: xii).
}

Sudama, I. N. (2020). Conflict within tri hita karana's fields: A conceptual review. International Journal of Linguistics, Literature and Culture, 6(6), 8-23. https://doi.org/10.21744/ijllc.v6n6.992 
behaviours are the key to achieve equilibrium of the balance between spiritual, natural and human worlds. In this context, Ardika argues that managing greed and desires is the key to achieve balance life and he further quotes the Mahatma Gandhi that " there is a sufficiency in the world for man's need but not for man's greed" (Peters \& Wardana, 2013).

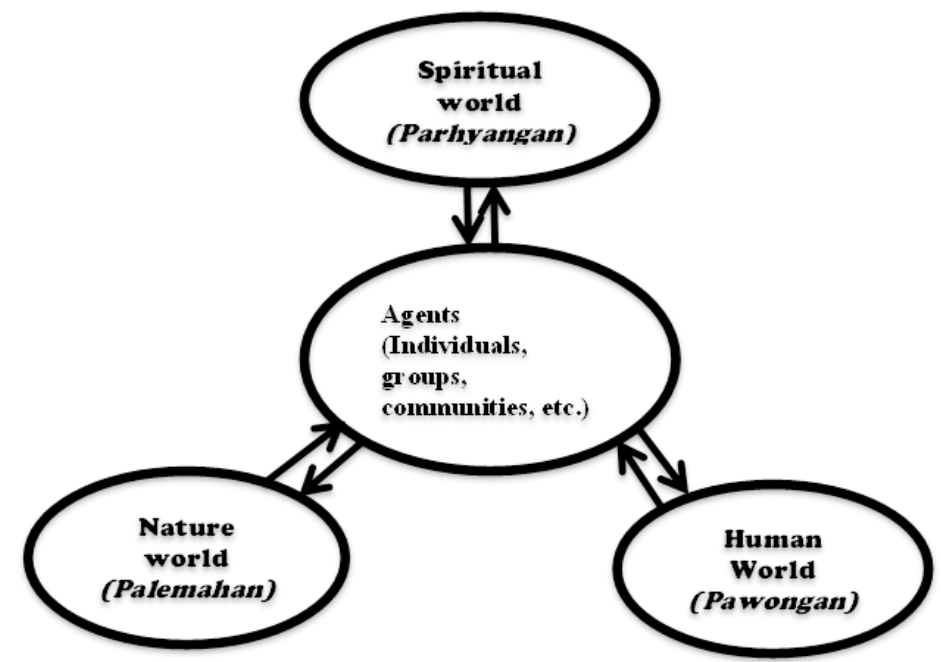

Figure 1. Tri Hita Karana diagrammatic (Author elaboration from several sources such as Suartika, 2005; Siadis, 2014).

THK has been widely applied by Balinese villagers in many areas of life and agricultural practices (Peters \& Wardana, 2013). The practices of THK include (1) spiritual in the form of piodalan, (2) social in the formation of desa adat and banjar (Balinese traditional organization), and (3) territorial in which there is the distinction between human and nature by building candi bentar (traditional gateway entrance). Suartika (2005), explains that the THK is a concept of harmonious interrelation among human-God and the environment which subject to space, time, and situation (desa, kala, and patra). The contradiction or disruption of the interrelation equilibrium will cause a conflict in social systems. However Suartika (2005), argues that conflict is not a thing that should be kept away from Balinese life but it is a possibility to sort out a problem into prospects by employing the concept of desa, kala, and patra. This view is based on the belief and daily life observation of Balinese in that good and bad or conflict and peace are two sides of the same coin (rwa bhineda). The rwa bhineda concept is in a similar line to the Busino (2009), who argues that the social equilibrium is the state in a particular condition that can be disrupted by any kind of forces. Further, he explains that the disruption means another movement toward a new equilibrium that is the possibilities imply in the presence of conflict.

\section{Galtung's Triangle}

To explain the framework of THK as a conflict of capital and to understand the policy for conflict transformation, this paper employs Galtung's ABC triangle as conceptual support (Figure 2). Galtung draws special attention to a general type of conflict or violence. He formulates the relationship of conflict components and then escalates contradictory interests (Galtung, 1996). They can be seen as a side by side of attitude and behavior while the contradiction in the top (Stalenoi, 2014). The triangle can be utilized to explain how the conflict occurs as a result of the change of the three components. 


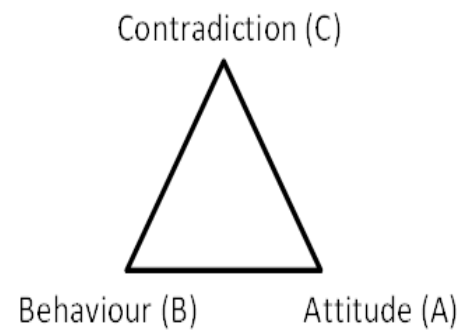

Figure 2. Galtung's ABC triangle

Galtung proposes that the triangle is flexible in which can be started in any of the three components with different explanations and analyses. Therefore, the three corners are interchangeable where $\mathrm{A}, \mathrm{B}$, and $\mathrm{C}$ invigorate one another to form incompatible objectives to the vertical conflict. Consequently, the triangle can also be utilized as a conflict transformation analysis since the different angles of analysis of the $\mathrm{A}, \mathrm{B}$, and $\mathrm{C}$ is not only in the presence of conflict but also the evolution of peace.

Galtung's $\mathrm{ABC}$ is not just a simple relation among its elements but requires a comprehensive understanding of analyzing conflict cycles (Drago, 2015). Conflicts are not a straight line and constant thinking but a complex and dynamic cycle (Gallo, 2013; Schulz, 2012). The triangle is simple when the conflict analysis starts from one of its corners however the justification of correlations among behavior, attitude and contradiction are not straightforward. Galtung (1996), states that "there is no simple relation between conflict and conflict behavior as long as the doubleness of conflict is taken into account" which implies that interdisciplinary and integrated frameworks are essential in the conflict analysis.

Considering behavior as the center of interest of disagreements between agents in the social system is an effortless conflict examination. The focus in one aspect of the triangle will guide our comprehensive knowledge in one angle without having all the necessary pieces of the conflict evolution. Therefore in this paper, the conceptual structures combine knowledge and unique traditions that are specific to a culture or a group of people.

\section{Creativity}

Creativity is widely recognized as activities of transforming steady state arrangement into dynamic valuable shapes. Consequently, it has been analyzed in the form of innovation and idea transformations (Kilroy, 1999; Bradley et al., 2012; Adams, 2005; Mehta et al., 2014; Parjanen, 2012). The most general definition of creativity still debatable but we can argue that creativity is an activity that can manifest in products that give a new segment of understanding or real products that fill the gap in a particular sector. A more comprehensive statement of creativity is proposed in De Miranda et al. (2009), as follows:

"Creativity is broadly accepted as a strategic, intangible, productive factor not only within the realm of the creative industries (artisans, visual and performing arts, film and audiovisual media makers, multimedia, literature, books, and publishing) but also on a much wider scale of entrepreneurial activities, sharing so many links with an extensive network of activities related to a multitude of businesses: from telecoms, software and video games, for example, to design, tourism and music, that its relationship to innovation becomes increasingly more intertwined and valued".

In the advance of information and communication technologies, creativity becomes more expanding areas compare to before the digital revolution takes place. This makes the definitions of creativity vary among different scholars. Roweton (1970), suggests that creativity definition can be viewed from sensitivity, originality, practicality, product and process, and morphological synthesis ${ }^{i}$. For this paper, the creativity is based on the practical point of view in which is explained as the way that something is ordered about other things to construct a useful transformation.

${ }^{i}$ Roweton (1970) also classified the definition of creativity based on combination and originality and practicality Sudama, I. N. (2020). Conflict within tri hita karana's fields: A conceptual review. International Journal of 


\section{Results and Discussions}

\section{THK literature}

The 37 THK studies under review in this paper were published in more than fourteen journals which constitute different areas of research with various backgrounds of analyses ${ }^{j}$. The studies examine numerous topics including environment, management, society and development, tourism and hospitality, education, agriculture, finance, and conflict resolution. Among them, 29 articles $(78.38 \%)$ discuss Bali as a whole and only 8 papers $(21.62 \%)$ explore THK at the microlevel (company, village, or specific community).

A majority of the THK papers applied qualitative methodologies (45.95\%), followed by literature reviews (24.32 $\%)$, and empirical studies (16.22\%). The rest of the paper use mixed methods $(13.51 \%)$ as a result of the growing complexities of social and cultural research therefore the adoption of the method gives flexibility and a triangulation approach to researchers for analyzing research findings (Schulenberg, 2007; Brent \& Kraska, 2010). The qualitative studies were characterized by some steps involving an interview, focus group discussion, unit study observation, and qualitative survey. Conversely, empirical studies use quantitative data to explain their findings and employ regression and statistic descriptive to develop statistical models to show a correlation among variables. Overall, the studies under review show their qualities of conceptual and analytical methods which indicates an accurate illustration of the research method.

Twelve studies $(32.43 \%)$ conclude that THK is the source of guidance for tourism, economic, and regional development. This is a global trend that culture has been considered an integral part of the regional development master plan since three decades ago as a primary source of competitiveness, development resources, and cultural assets (Ilmonen, 2015). In the context of regional strategy recommendation, the THK framework put on at least two directions to the policy development advice. First, THK helps regional policymakers to focus on each of the palemahan, pawongan, and parhyangan as their units of measurement and evaluation. Secondly, THK calls special attention to the balance and harmonious relationship between its three elements where a compromise has to be decided in achieving welfare or well-being. At the corporate level, THK has also been appointed as an organizational value or source of counseling to resolve typical problems $(24.32 \%)$.

Some literature $(10.81 \%)$ viewed THK as a valued defender to avoid the negative impact of globalization on Balinese traditions. THK keeps Balinese well balanced and sensible in their tradition to overcome inappropriate values that contradict to adat (traditional rules of conduct) Bali. Likewise, despite harmony relations between THK worlds, five studies $(13.51 \%$ ) also relate THK to the conflict in Balinese communities. These studies support the finding that the effect of modern life on Balinese traditions or cultures could lead to invisible conflicts that potentially emerge at any time in the future. Therefore some studies (13.51\%) warn that THK should be adopted as the philosophy of subak as the world cultural heritage to support Bali's sustainable development programs. Two studies mentioned that THK is a universal reference for global development and argues that the concept is similar to the sustainability notions that emphasize the balance between economic, nature, and social life.

\section{The THK's Fields}

The taxonomic distinctness in outlining parhyangan, palemahan, and pawongan as a world (Siadis, 2014; Adityanandana, 2017) should be naturally designated as a field in association with Bourdieu theory (Figure 3$)^{\mathrm{k}}$. The figure implies that the field is a structure of correlation between agent capital features which are expressed into practice to their secure positions. Therefore, each of the THK elements has its own rules and boundaries as the game areas of agents. They are dominated by their capital as an agent advantage to shape their roles in the Balinese society. The explanation of the dominated capital does not mean that there is only one kind of capital in the fields rather other preexisting or reproduced capital could also form the formation of the fields.

\footnotetext{
j The studies include Aditya and Kusuma (2019), Adityanandana (2017), Agung et al. (2020), Arjawa and Jayantiari (2017), Atmadja et al. (2019), Budhiastra (2016), Ernawati (2015), Gandhiadi et al. (2017), Sedana (2020), Ginaya et al. (2019), Hariana and Kasiyan (2018), Iswari et al. (2018), Kusuma et al. (2018), Lanya et al. (2017), Lorenzen and Lorenzen (2005), Coordinating Ministry of Human Development and Culture Republic of Indonesia (2015), Mudana et al. (2018), Narottama et al. (2018), Norken et al. (2017), Parker (2011), Pickel-Chevalier and Budarma (2016), Purnaya, (2016), Satya and Lase (2018), Siadis (2014), Astuti et al. (2018), Suamba and Sutama (2017), Suarniati et al. (2019), Suartika (2005), Sukarma (2016), Sumadi (2016), Sutawan (2004), Suweta (2015), Triyuni et al. (2019), Vita et al. (2018), Wiranata et al. (2012), Wesnawa and Suastra (2016), Wijaya and Artajaya (2020), Wright (2019).

${ }^{k}$ For the different point of view in using world over the field analysis can be seen in Bottero and Crossley (2011).
} 
The formations in Figure 3 also show that THK's fields are characterized by dominated capital as agent equipment to maintain their bases, therefore the field itself is an area of conflict and contestation. The field gives a boundary to the agents to compete for a certain capital that is specific to that field. The THK relations underpin the field notions by allowing the movement of agents in the three different fields as a result of their struggles to gain profits or capital. As the fields are independent of each other or self-governing, the movements of the agent between THK's fields are the effort of Balinese to find their goals in life. Consequently, every field has its own goal of life which is specific to it. That is why the THK requires the balance of the three fields to fulfill the Balinese ultimate goal that is Mokshartham Jagadhita Ya Ca Iti Dharma (happiness in the world and liberation afterward).

This goal is a theoretical spiritual domain that has to be practiced in daily life. Every field in the figure was related to four Balinese practical life goals (Catur Purusa Artha) involving wealth (Artha), pleasure (Kama), righteousness (Dharma), and liberation (Moksha). The practical goals have to be achieved by four stages of life including Brahmacari (educational phase), Grahasta (marriage step), Vanaprashta (forest dweller-retirement), and Sanyasin (spiritual stage). These steps of Balinese human growth are well known as the Catur Asrama (four steps of human life).

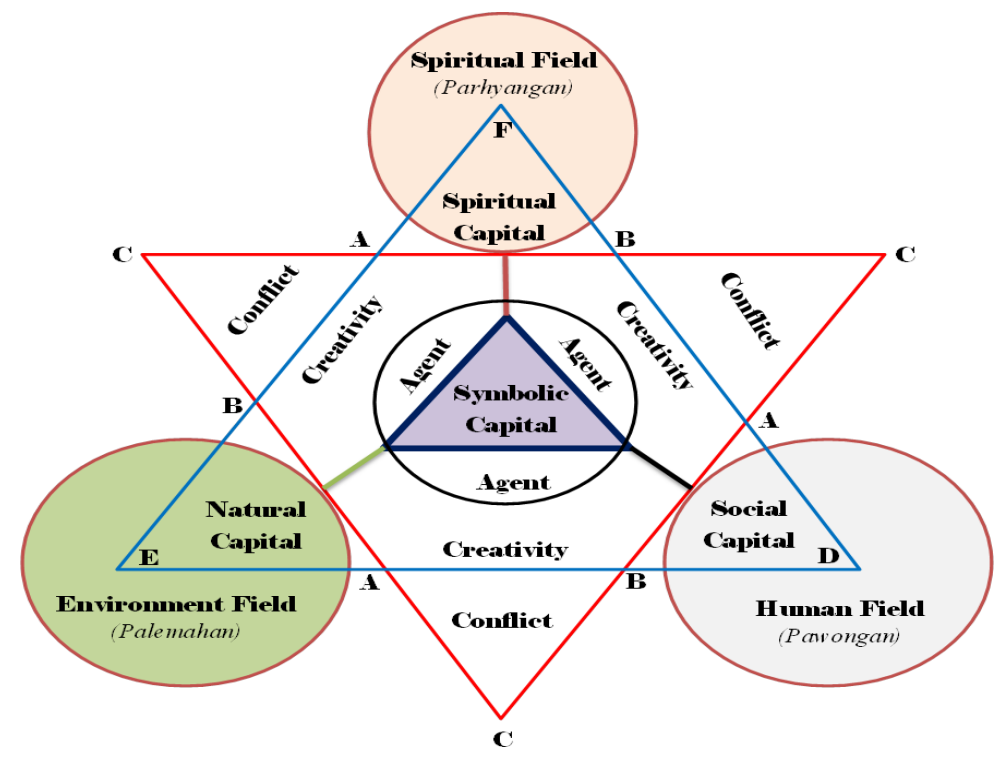

Figure 3. Extended THK framework.

Within the spiritual field, the Balinese engage in sanyasin at any point in time through their life cycles. The goal of the Balinese in the spiritual field is to achieve moksha. The sanyasin is a general position that is not a certain position defined by the economic theory. The sanyasin as a Bourdieu position is determined by what Balinese do and what kind of roles they play in the spiritual field. The different positions have various levels of status. The highest and reputable position in the spiritual field is Pedanda (a Hindu scholarly high priest). Other positions are Pemangku (priest for particular temple), Sadhu (spiritual practitioner), Yogi (yoga specialist), Biksu (Budhis priest), just to name a few.

The spiritual field is an independent space structured by spiritual capital in the form of specific tasks or abilities owned by sanyasin position. The abilities involve know how to pray in mantra (pray with Sanskrit words or their translation), read traditional Balinese roles (uger-uger, padewasan), understand Balinese spiritual philosophies and theologies, knowledge of yadnya (Balinese ceremonies), read ancient writing (lontar), master in traditional medicines, and perceptions of Balinese physical and metaphysic (sekala-niskala). Similar to the Bourdieu notion of cultural capital, the spiritual capital is often operationalized as a level or degree of knowledge of spiritual practices that are clearly defined in the Balinese social system.

The environment field is the second field (Figure 3) which is interpreted as a complex space constituted of Balinese as an individual, the government as the lawful body, banjars and desa adats as a traditional cultural organization, and other agents as part of nature conservation and environmental scientists, engineers, or sustainability campaigners. The Balinese who practices vanaprastha could also be the agent in this field since in the past the term was used to those who move closer to nature by living in a forest for self-improvement. Some literature mention about the global field (Buchholz, 2016), geoengineering (Olsson \& Jerneck, 2018) or environment capital (Karol \& Gale, 2004) that may relate environment or nature as a field. The rules of nature govern the field and this field is a subset of the universe.

Sudama, I. N. (2020). Conflict within tri hita karana's fields: A conceptual review. International Journal of

Linguistics, Literature and Culture, 6(6), 8-23. https://doi.org/10.21744/ijllc.v6n6.992 
Agents within the environment field generate activities and meanings based on inherent qualities of mind and characters ${ }^{1}$. Simultaneously, these qualities produce new practices trough unpredictable assessment of differentiation.

In the field of environment, there are stocks of non-renewable and renewable natural resources as natural capital. These include soil, water, air, forests, sea life, plants, animals, minerals, and other resources that provide advantages to people. The agents in the field of environment use pre-existence capital to explore natural capital. In Balinese tradition, this natural capital is the manifestation of five elements which consist of ether (akasha), air (bayu), fire (teja), water (apah), and earth (pertiwi). The engagement of Balinese and other agents in Bali's environment field is in the form of ceremonies. The ceremonies help Balinese to ensure the appropriate use of natural capital for sustainability purposes.

The human world of THK can be seen as a distinguished autarchic field in which a self-governing space where rules of conduct are applied. Human actions lie upon rules and regulations and human relations govern by specific roles related to others. The rules and regulations affiliate and trigger the interchange in the social system of human fields. Social capital is the relation and network that give power to the owner to be better off compare to others. Although there are economic activities that are based on the economic capital in this field the interchangeable connections in the form of networks, cohesion, and trust as a form of social capital are the most influenced capital.

The grahasta could be the main step of life for Balinese in the human field. Balinese in this stage seeks artha and kama as the main goals. Brahmacharya also part of this field in the sense that the Balinese acquire knowledge through social transfers and educational institutions ${ }^{\mathrm{m}}$. When the artha and kama begin to be the prestigious aspect of Balinese, a rivalry in the human field increase its intensity, and hence social capital is used as a tool to be successful in the competition. In this case, artha which means wealth as economic capital is considered as a life goal shaping struggles within the human field.

\section{Conflict of Capital}

Figure 3 depicts that the agents entre each field of THK with their inherent capital by doing activities. The activities are bounded by the balance line triangle (DEF) in which agent attitudes and behaviors follow the Balinese principles of life. Based on Velikovsky $(2012,2018)$, the activities can be classified as creative or non-creative. The creative activities became famous, viral, or deserve recognition within a particular field or across other fields. As a result, they gain symbolic capital because of their products or contributions. Therefore, the symbolic capital comes to the system as a consequence of capital transformations.

Another requirement to be classified as creative activities is that if they are carried out within the triangle of balancing the relationship between fields. If the activity is out of the balancing triangle then the creative attitudes and behaviors tend to trigger confrontation and hence conflict occurs. Specifically, as long as the activities in the area of balance relation between parhyangan, palemahan and pawongan fields then there will not be a conflict in the social system which is the conventional view of the THK philosophy.

The ABC triangle in Figure 3 reveals that contradiction is generated by unbalancing behaviors and attitudes. These interferences come to the THK framework which engenders the construction of the contradiction in the form of violence or confrontations. In the case that attitudes and behaviors arise in the opposite direction that cannot solve their deviation toward divergence interests then they will trigger the top corner of contradiction. Conversely, when behaviors and attitudes work in the same framework toward equilibrium relation of THK's fields, the creative outcomes will be the high end of Balinese cultural products recognized worldwide like gamelan (traditional music), barong, and kecak dances, traditional arts, to name just a view. This means that unnecessary changes in the THK's fields that oppose the life purpose moksartham jagatdhita ya ca iti dharma will cause conflict in Balinese society.

In contemporary Bali, there are some sources of conflict such as life opportunities as competition take place, the economic point of view in which the imbalance resource and human needs, and different power among agents and capital distributions. Consequently, there must be a high level of diversity across THK's fields with a variety of opposing interests. Hence, Balinese behaves in various directions to yield maximum advantages. Balinese who have more powers in the form of capital dominate the fields by choosing policies for their interests. Conversely, the less capital owner accepts the rule of regulations in place. In this case, powerful agents want to control society for the purpose of maintaining their status quo of acquiring legitimacy and other forms of capital. These tendencies affect the perpetuation of social classes colored by the chronic discrepancy of wealth and capital. This means that capital in

\footnotetext{
${ }^{l}$ This inherent of characters and qualities is part the concept of Bourdieu habitus (Bourdieu, 1986).

${ }^{m}$ Barhmacarya as religious and spiritual stages can also be seen in spiritual and environment field.
} 
Bourdieu's point of views function as an established process by which new classes emerge ${ }^{\mathrm{n}}$. Therefore, the claim of capital for legitimation becomes the seed of contentions, thus the domination among capital shapes the fields as a class struggle to preserve their status quo.

However, if at least one of the agents in the THK's fields challenges the outcome of the status quo then Figure 3 will be in unbalanced situations. As a result, agents polarize in random directions out of the balance triangle DEF. Hence, we can conclude that the Balinese will be in a situation of conflict. In the long term, social classes and unbalance powers in the Balinese social system will continue to be created and multiplied through family transmissions, clan relations, community exclusivism, and formal and informal educations.

In Bali, the class was part of the Hindu's religious hierarchical order (kasta) that divided Balinese into four castes with Brahmana (ritual and spiritual specialist) at the highest level, followed by Ksatria (skillful fighter), Weisya (businessman), and Sudra (laborer). Based on Bhagavad Gita, the Balinese kasta is not to be inherited to the family member and it was designated based on karma. Bhagavad Gita mentions that (Rao, 2015):

“cāturvarṇyam mayā sṛștam guṇa-karma-vibhāgaśah””

"The structure of four varna is created by me according to the innate dispositions of people and duties have been assigned".

However, in the case that kasta views Bourdieu's class, caste can be assigned as a social system establishment that is replicated through family or clan transfers and hence can be reproduced throughout social structures of differentiation. Therefore, caste in the form of cultural capital is considered to be part of economic redistribution shaping inequality and unfair treatments. Consequently, as stated by Lizardo (2011) that cultural capital can also lead to conflict. He explains as below

“...cultural sociology as a theorist of 'culture and power' armed with specific conceptualizations of culture useful for dealing with the perennial problem of the relationship between class, status, and power..."

Lizardo explanation implies that Bourdieu's cultural capital like Balinese kasta is a kind of force that can set off a perpetuation of the clash between classes, statuses, and powers in a particular field.

The conflicts of class in the form of caste disputes in Bali become prominent since the difference of opinions between Balinese mass organizations (ormas), Surya Kanta, and Bali Adnyana in the 1920s (Picard, 2004). Latter the disagreement about class in Bali becomes open social conflicts that include physical actions of causing material losses. However, the rise of contemporary society, the influence of tourism, and economic development that promote human rights, democracy, and equality would naturally lessen the caste conflicts and the traditional Balinese kasta-based inequalities.

Other forms of conflict in Bali are explained in (Hobart, 2017; Parker, 2011; McDonald \& Wilson, 2017). Hobart mentions that the conflicts in Bali are caused by the missing link of solidarity. Parker (2011), argues that the Balinese people face a dilemma between showing their culture as a tourist attraction and the pressure of disharmony among THK worlds as a result of modern life. McDonald \& Wilson (2017), explained how the Balinese culture movement may affect the emergence of security contestations as friction in Balinese societies.

All of these conflicts can be traced back as a capital dispute in the THK framework since the sources and roots of the problem are the efforts to maintain agent positions in Balinese society. The inequalities of income distribution and the missing link of solidarity as mentioned in Hobart (2017) and Parker (2011), are the issues of economic capital spreading among Balinese as part of tourism development booms. Only some people own the big portions of the tourism income seem to be potential sources of conflict in the future. In addition, there is a gap in economic capital distribution between the Indonesian central government and the Balinese regional government in the form of Balinese tourism revenues (Izawa, 2009). The gap manifests in several problems in Bali development programs as the revenues cannot be maintained for better developments and hence the Balinese qualities of life.

Further Izawa (2009), argues that the conflicts exist in Balinese communities because of a lack of understanding to implement the Balinese cultural capital. Izawa mentioned that:

\footnotetext{
${ }^{n}$ This conceptual position is the core source of the conflict in THK framework since the views of capital is different with capital as public good (benefit for all agents) but rather the Bourdieu concept of capital stand for the perseverance of inequality among agents in the field.
}

Sudama, I. N. (2020). Conflict within tri hita karana's fields: A conceptual review. International Journal of 
"As we have seen already, Balinese communities and agencies actively appeal and often impart the idea of Tri Hita karana in its policy; however, it is doubtful if they truly understand the idea and try to practice it in their daily life. Rather we can find the cases that Balinese themselves cause the social issues to become serious"

The benefit of the natural capital that has been explored in tourism development should increase the existing economic capital in Bali. In turn, economic capital can be managed to improve the Balinese standard of living. However, Izawa (2009), found that the Balinese still struggle in achieving better standards of living by taking examples of the conflict of the illegal cafe, preman (local gangs), and waste problems.

The conflict between the capital in THK's fields may also be described in the overlapping contestations of symbolic capital, social capital, and cultural capital in the arrival of localized militia groups or ormas (McDonald \& Wilson, 2017). They stated that:

\footnotetext{
"The contestation of cultural values, forms of identity, claims to authority and even control networks of criminal activity overlap because they are contested in the same security space and articulated through the same registers of prowess and violence"
}

The symbolic capital (forms of identity), social capital (networks), and cultural capital (cultural values) have been used by some Balinese to continue their activities for personal or group advantages. As mentioned by McDonald \& Wilson (2017), that some people use the jargon of security to gain positions in the Balinese community by declaring that their activities protect Balinese culture. By using community organization (banjar) as background, the ormas operates their businesses that potentially trigger conflicts at any time in the future since an overlapping task and interest persist among ormas, legal security organizations, and Balinese communities.

\section{Conclusion}

The original concept of THK has been known as a balance concept of harmony and happiness in life. However, the THK framework still silences in the presence of cultural conflicts in Bali which are considered important as part of another Balinese life principle called rwa bhineda. This paper tries to fill this gap by offering other dimensions of THK to explain that conflict is an integral part of the concept by using a Bourdieusian analysis and a review method. This conceptual analysis is critical to give a better understanding of the present conflict in Bali like ormas and cultural conflicts.

The Bourdieusian analysis assists to illustrate the root of the conflicts in the modern Balinese era because it considers the dynamic of agents within and across fields. Within THK-Bourdieu concepts, Capital plays important role in the Balinese life balance. Capital determines the position, status, competition, and hence symbolic values of agents in the fields. Bourdieu's class analysis also helps to explain the conflict in the form of caste misinterpretation among different clans in Bali. The integration of the Bourdieu framework into the THK concept enables us to embrace a wide range of theoretical ideas which make it possible to have a rich coherent argument in explaining the conflict between groups of actors. This provides a different perspective for recognizing the elements of social conflicts and their courses to find a sustainable dispute resolution.

The conceptual framework in this paper is based on the combination and integration of conceptual frameworks of different fields of studies that tailoring the main concept of THK. To gain more insight from the presented new framework, the empirical analysis of the framework will show more complete descriptions of the THK in the real world. A project-based study to explore the built framework will give an actual distribution of capital in the THK's fields and explore the potential conflicts within Balinese societies in the future. For further research, conflict transformations by using this new framework will also be possible with deeper problem solving analyzed in statistical modeling. 
Conflict of interest statement

The author declared that he has no competing interests.

Statement of authorship

The author has a responsibility for the conception and design of the study. The author has approved the final article.

Acknowledgments

This article is part of my research on Balinese mass organisation conflict during my doctoral program. I would thank to my brother who shares his experiences in guiding me to do my research. For those who helped me to complete this paper on time, I would also like to say thank you.

Sudama, I. N. (2020). Conflict within tri hita karana's fields: A conceptual review. International Journal of 


\section{References}

Abouelsaood, A., Callan, C. G., Nappi, C. R., \& Yost, S. A. (1987). Open strings in background gauge fields. Nuclear Physics B, 280, 599-624. https://doi.org/10.1016/0550-3213(87)90164-7

Adams, K. (2005). The Sources of Innovation and Creativity. National Center on Education and the Economy (NJ1).

Aditya, A. G. D., \& Kusuma, M. G. W. (2019). The effect of tri hita karana culture in relationship between work stress and internal auditor performance. International Research Journal of Management, IT and Social Sciences, 6(2), 72-78. https://doi.org/10.21744/irjmis.v6n2.610

Adityanandana, M. (2017). Amidst Mass Tourism: Tri Hita Karana and Conflict of Valuation Languages. Master Thesis, Institute of Social Study, Netherland.

Adityanandana, M., \& Gerber, J. F. (2019). Post-growth in the tropics? Contestations over Tri Hita Karana and a tourism megaproject in Bali. Journal of Sustainable Tourism, 27(12), 1839-1856.

Agung, A.A.G., Suprina, R., and Nugroho, A. (2020). BALI - A Traditional Society in Transformation. Journal of Culture, Society and Development, 59(2020), 14-18.

Allen, P., \& Palermo, C. (2005). Ajeg Bali: Multiple meanings, diverse agendas. Indonesia and the Malay World, 33(97), 239-255.

Arjawa, I. B. S., \& Jayantiari, I. M. R. (2017). Democratic values in Balinese traditional society: Analysis of the making and the content of Desa Pakraman's awig-awig. Masyarakat, Kebudayaan dan Politik, 30(4), 428-436.

Asimaki, A., \& Koustourakis, G. (2014). Habitus: An attempt at a thorough analysis of a controversial concept in Pierre Bourdieu's theory of practice. Social Sciences, 3(4), 121-131.

Astuti, N. N. S., Ginaya, G., \& Susyarini, N. P. W. A. (2019). Designing Bali tourism model through the implementation of tri hita karana and sad kertih values. International journal of linguistics, literature and culture, 5(1), 12-23. https://doi.org/10.21744/ijllc.v5n1.461

Atmadja, A. T., Saputra, K. A. K., \& Manurung, D. T. (2019). Proactive fraud audit, whistleblowing and cultural implementation of tri hita karana for fraud prevention.

Bennett, T. (2005). The historical universal: the role of cultural value in the historical sociology of Pierre Bourdieu. The British Journal of Sociology, 56(1), 141-164.

Bennett, T., \& Silva, E. B. (2006). Introduction cultural capital and inequality: Policy issues and contexts. Cultural Trends, 15(2-3), 87-106.

Bottero, W., \& Crossley, N. (2011). Worlds, fields and networks: Becker, Bourdieu and the structures of social relations. Cultural sociology, 5(1), 99-119.

Bourdieu, P., \& Richardson, J. G. (1986). Handbook of Theory and Research for the Sociology of Education. The forms of capital, 241-258.

Bradley, S. W., McMullen, J. S., Artz, K., \& Simiyu, E. M. (2012). Capital is not enough: Innovation in developing economies. Journal of Management Studies, 49(4), 684-717.

Brent, J. J., \& Kraska, P. B. (2010). Moving beyond our methodological default: A case for mixed methods. Journal of Criminal Justice Education, 21(4), 412-430.

Buchholz, L. (2016). What is a global field? Theorizing fields beyond the nation-state. The Sociological Review, 64(2_suppl), 31-60.

Budhiastra, I. M. M. (2016). An essay on Karma Karana: A notion on restructuring the Bali hospitality and service industry by re-establishing the concepts of Tri Hita Karana and Karmaphala. Research in Hospitality Management, 6(2), 219-224.

Busino, G. (2000). The signification of Vilfredo Pareto's sociology (No. XXXVIII-117, pp. 217-228). Librairie Droz.

Chan, J. (2004). Using Pierre Bourdieu's framework for understanding police culture. Droit et société, (1), 327-346.

Coordinating Ministry of Human Development and Culture Republic of Indonesia (2015) Integrated Agricultural System of Tri Hita Karana - Tri Mandala in Bali, Indonesia. Globally Important Agriculture Heritage System (GIAHS) Initiative, Bali Indonesia

Croce, M. (2019). The Levels of Critique. Pierre Bourdieu and the Political Potential of Social Theory. Sociologica, 13(2), 23-35.

De Miranda, P. C., Aranha, J. A. S., \& Zardo, J. (2009). Creativity: people, environment and culture, the key elements in its understanding and interpretation. Science and Public Policy, 36(7), 523-535.

Demetrion, G. (2000). Practitioner-based inquiry: Theoretical probings. Adult Basic Education, 10(3), 119-146.

Drago, A. (2015). Improving Galtung's abc to a scientific theory of all kinds of conflicts. Ars Brevis, (21), 56-91.

Ernawati, N. M. (2015). Producer-market orientation of community-based tourism (CBT) products: A case study in Bali, Indonesia. 
Fowler, B. (1999). Pierre Bourdieu's sociological theory of culture. Variant, 2(8), 1-4.

Gallo, G. (2013). Conflict theory, complexity and systems approach. Systems Research and Behavioral Science, 30(2), 156-175.

Galtung, J. (1996). Peace by peaceful means: Peace and conflict, development and civilization (Vol. 14). Sage.

Gandhiadi, G. K., Sudibia, I. K., Suyana Utama, I. M., \& Saskara, I. A. N. (2017). The influence of social capital on subjective wellbeing: a structural model for the weaving industry in Bali province of Indonesia. International Journal of Economics Commerce and Management, 5(6).

Ginaya, G., Sudarmini, N. M., \& Damayanti, I. K. W. (2019). Tri hita karana and sad kertih values in Belimbing rural tourism development. International journal of social sciences and humanities, 3(2), 10-23.

Gordon, S. P. (2016). Expanding our horizons: Alternative approaches to practitioner research. Journal of Practitioner Research, 1(1), 2.

Grusendorf, S. (2016). Bourdieu's field, capital, and habitus in religion. Journal of Sociology and Christianity, 6(1).

Hariana, K., and Kasiyan. (2018) Eco Art Education through the Indigenous Wisdom Concept of Tri Hita Karana. Advances in Social Science, Education and Humanities Research, (327), 96-102.

Hendrik, P. J., \& Wardana, W. (2013). Tri Hita Karana: The Spirit of Bali. Gramedia, Jakarta.

Hobart, M. (2017). Bali is a battlefield Or the triumph of the imaginary over actuality. Jurnal Kajian Bali (Journal of Bali Studies), 7(1), 187-212.

Ilmonen, K. (2015). The role of culture in regional development work-changes and tensions. In Harnessing Place Branding through Cultural Entrepreneurship (pp. 79-95). Palgrave Macmillan, London.

Izawa, T. (2009). Tourism Development and Its Social Impacts in Bali, Indonesia in the Post-Soeharto Era. Memoirs of Institute of Humanities, Human and Social Sciences.

Jaakkola, E. (2020). Designing conceptual articles: four approaches. AMS Review, 1-9.

Karol, J., \& Gale, T. (2004). Bourdieu's social theory and sustainability: What is 'environmental capital'. Australian Association for Research in Education.

Kilroy, D. B. (1999). Creating the future: how creativity and innovation drive shareholder wealth. Management Decision.

Kusumaa, I. G. A. T., Landrab, N., \& Widnyanac, W. (2019). Construction of Welfare Mediation Model Based on Tri Hita Karana on The Economic Effect of Tourism Sector Toward Happiness To Improve Life Satisfaction of Local Community.

Lanya, I., Dibia, I. N., Diara, I. W., \& Suarjaya, D. G. (2017, December). Analysis of Subak Landuse Change Due to Tourism Accomodation Development in North Kuta Sub-district, Badung Regency, Indonesia. In IOP Conference Series: Earth and Environmental Science (Vol. 98, No. 1, p. 012024). IOP Publishing.

Lizardo, O. (2011). Pierre Bourdieu as a post-cultural theorist. Cultural Sociology, 5(1), 25-44.

Lorenzen, S., \& Lorenzen, R. P. (2005, August). A case study of Balinese irrigation management: institutional dynamics and challenges. In Second Southeast Asia Water Forum. Nusa Dua, Bali.

Lukka, K., \& Vinnari, E. (2014). Domain theory and method theory in management accounting research. Accounting, Auditing \& Accountability Journal.

McDonald, M., \& Wilson, L. (2017). Trouble in paradise: Contesting security in Bali. Security Dialogue, 48(3), 241258.

Mehta, M., Chandani, A., \& Neeraja, B. (2014). Creativity and innovation: assurance for growth. Procedia Economics and Finance, 11, 804-811.

Mudana, I. G., Suamba, I. B. P., Putra, I. M. A., \& Ardini, N. W. (2018, January). Practices of Bali Tourism Development, Threefolding, and Tri Hita Karana Local Knowledge in New Order Indonesia. In Journal of Physics: Conference Series (Vol. 953, No. 1, p. 012108).

Mutisya, E. (2011). Conflict Analysis and Resolution: Socio-cultural and Intrapersonal Perspectives. Peace and Conflict Monitor, University of Peace. https://www.ideasforpeace.org/content/conflict-analysis-and-resolutionsocio-cultural-and-intrapersonal-perspectives.

Narottama, N., Abdillah, F., Nirmalayani, I.A. (2018). Religion as "The Last Fortress" of Bali Cultural Tourism. Paper presented at the International Conference on Emerging Tourism Destinations 2016, in Dili Institute of Technology, Timor Leste, 24-26 October 2016.

Norken, I. N., Suputra, I. K., Arsana, I. G. N. K., \& Ngurah, I. G. (2017). Institutional and Regulatory Roles in Maintaining Sustainability of Subak as a World Cultural Heritage in Bali. Asian Agri-History, 21(4), $245-254$.

Olsson, L., \& Jerneck, A. (2018). Social fields and natural systems. Ecology and Society, 23(3).

Sudama, I. N. (2020). Conflict within tri hita karana's fields: A conceptual review. International Journal of Linguistics, Literature and Culture, 6(6), 8-23. https://doi.org/10.21744/ijllc.v6n6.992 
Parjanen, S. (2012). Experiencing creativity in the organization: From individual creativity to collective creativity. Interdisciplinary Journal of Information, Knowledge \& Management, 7.

Parker, G. S. (2011). Living in two worlds: how tourism has influenced the Balinese worldview of Tri Hita Karana: a thesis presented in partial fulfillment of the requirements for the degree of Master of Arts in Social Anthropology at Massey University, Albany, New Zealand (Doctoral dissertation, Massey University).

Picard, M. (2004). What's in a name? Agama Hindu Bali in the making. Hinduism in Modern Indonesia. A Minority Religion Between Local, National, and Global Interests. London/New York: RoutledgeCurzon, 56-75.

Pickel-Chevalier, S., \& Ketut, B. (2016). Towards sustainable tourism in Bali. A Western paradigm in the face of Balinese cultural uniqueness. Mondes du tourisme, (Hors-série).

Purnaya, I. G. K. (2016). The ideology that affects the management of tourist resort Nusa Dua-Bali. International journal of linguistics, literature and culture, 2(4), 72-80.

Rao, K.A. (2015). A Guide to Bhagavad Gita. Ritunestham Press, Hyderabad, India.

Ringmar, E., \& Identity, I. (1996). Action: A Cultural Explanation of Sweden's Intervention in the Thirty Years War.

Rothman, J., \& Olson, M. L. (2001). From interests to identities: Towards a new emphasis in interactive conflict resolution. Journal of Peace Research, 38(3), 289-305.

Roweton, W. E. (1970). Creativity: A Review of Theory and Research. Theoretical Paper No. 24.

Ruble, T. L., \& Thomas, K. W. (1976). Support for a two-dimensional model of conflict behavior. Organizational behavior and human performance, 16(1), 143-155. https://doi.org/10.1016/0030-5073(76)90010-6

Schulenberg, J. L. (2007). Analysing police decision-making: Assessing the application of a mixed-method/mixedmodel research design. International Journal of Social Research Methodology, 10(2), 99-119.

Schulz, M. (2012). A theory of social change and development: resistance and power and their inter-linkage with conflict and peace.

Shammas, V. L., \& Sandberg, S. (2016). Habitus, capital, and conflict: Bringing Bourdieusian field theory to criminology. Criminology \& Criminal Justice, 16(2), 195-213.

Siadis, L. M. (2014). The Bali Paradox: Best of Both Worlds. Leiden: Leiden University.

Snyder, H. (2019). Literature review as a research methodology: An overview and guidelines. Journal of Business Research, 104, 333-339. https://doi.org/10.1016/j.jbusres.2019.07.039

Solnik, B. H. (1974). An equilibrium model of the international capital market. Journal of economic theory, 8(4), 500524. https://doi.org/10.1016/0022-0531(74)90024-6

Stalenoi, I. (2014). " THE PEOPLE'S WAR" AND JOHAN GALTUNG'S CONFLICT MODELS. Revista de Administratie Publica si Politici Sociale, 12(1), 69.

Suamba, I. B. P., \& Sutama, I. K. (2017). Materiality and Spirituality in Bali Tourism: An Ethical Reflection on the Tri-Hita-Karana. International Journal of Applied Sciences in Tourism and Events, 1(1), 70.

Suarniati, I. G. A., Anom, I. G. N., \& Hengki, I. G. B. (2019). Reflection of Tri Hita Karana Philosophy as A Local Wisdom of Bali Communities in Responding to Social Conflict in The Global Reform Era. Sociological Jurisprudence Journal, 2(2), 127-133.

Suartika, G. A. M. (2005). Vanishing paradise: Planning and conflict in Bali (Doctoral dissertation, University of New South Wales).

Sukarma, I. W. (2016). Tri Hita Karana theoretical basic of moral Hindu. International journal of linguistics, literature and culture, 2(3), 102-116.

Sumadi, K. (2016). Tourism development basis in traditional village of Kuta. International journal of linguistics, literature and culture, 2(3), 124-132.

Sutawan, N. (2004, November). Tri Hita Karana and Subak. Search for an Alternative Concept of Sustainable Irrigated Rice Culture. Paper presented at the International Network for Water and Ecosystem in Paddy Fields Conference, Tokyo.

Suweta, I.G.N. (2015). Tri Hita Karana Concept (Local Wisdom as an Alternative in Environment Based Development Towards "Green Government”). The International Journal of Social Science, 33(1), 44-55.

Triyuni, N. N., Ginaya, G., \& Suhartanto, D. (2019). Catuspatha spatial concept in Denpasar city. International journal of linguistics, literature and culture, 5(3), 18-31.

Velikovsky, J. T. (2012). Creative Practice Theory'. StoryAlity, Wordpress. com, Sydney. http://storyality. wordpress. com/creative-practice-theory.

Velikovsky, J. T. (2018). The Holon/Parton Theory of the Unit of Culture (or the Meme, and Narreme): In Science, Media, Entertainment, and the Arts. In Technology Adoption and Social Issues: Concepts, Methodologies, Tools, and Applications (pp. 1590-1627). IGI Global. 
Vita, I. N. M., Dwija, P. I. A., Sadha, S. I., \& Ary, W. I. (2018). The Effect Of Good Corporate Governance And Tri Hita Karana Culture On The Quality Of Financial Reporting. Russian Journal of Agricultural and Socio-Economic Sciences, 78(6).

Wang, J. Y. (1990). Growth, technology transfer, and the long-run theory of international capital movements. Journal of international Economics, 29(3-4), 255-271. https://doi.org/10.1016/0022-1996(90)90033-I

Wesnawa, I. G. A., \& Suastra, I. W. (2016). Tri Hita Karana (THK) concept in rural settlements of Bali. Journal of Education and Social Sciences, 3, 75-78.

Wesnawa, I. G. A., \& Sudirta, I. G. (2017). Management of boundary areas based on Nyamabraya values. International journal of linguistics, literature and culture, 3(5), 63-71.

Wilterdink, N. (2017). The dynamics of inequality and habitus formation. Elias, Bourdieu, and the rise of nationalist populism. Historical Social Research/Historische Sozialforschung, 22-42.

Wright, T. (2019). Beyond the physical: Environmental relationships in Bali, Indonesia.

Sudama, I. N. (2020). Conflict within tri hita karana's fields: A conceptual review. International Journal of 